Quebec Cooperative Study

of Friedreich's Ataxia

\title{
Protein Kinase Activity of Human Erythrocyte Membranes in Friedreich's Ataxia
}

\author{
P. WONG and A. BARBEAU
}

SUMMARY: Proteins of human erythrocyte membranes of Friedrich's ataxia patients and controls were examined by SDS-polyacrylamide gel electrophoresis before and after reduction with $\beta$-mercaptoethanol. No difference could be detected in the composition of their state of aggregation. The protein kinase activity of human erythrocyte membranes of eleven Friedreich's ataxia patients and six controls was determined. No difference in their protein kinase activity could be detected. These results are discussed with respect to an involvement of a generalized membrane defect in Friedreich's ataxia.

RESUME: Les protéines des membranes érythrocytaires humaines de patients ayant l'ataxie de Friedreich et de contrôles furent examinées par électrophorèse sur gel de polyacrylamide en SDS, avant et après une réduction avec le $\beta$-mercaptoethanol. Aucune différence ne fut détectée dans leur composition, ou leur état d'aggrégation. L'activité de la protéine kinase des membranes erythrocytaires humaines fut déterminée chez onze patients avec l'ataxie de Friedreich et six contrôles. Aucune différence ne fut détectée dans l'activitée de la protéine kinase. Ces résultats sont discutés en rapport avec la participation d'un défaut membranaire généralisé dans l'ataxie de Friedreich.

\footnotetext{
From the Department of Neurobiology, Clinical Research Institute of Montreal.

Reprint requests for the complete supplement on Friedreich's Ataxia (phase three) to: Dr. André Barbeau, Clinical Research Institute of Montreal, 110 Pine Avenue West, Montreal, Quebec, Canada, H2W IR7.
}

\author{
INTRODUCTION \\ Previous studies have provided
} some evidence for a generalized membrane defect in Friedreich's ataxia. Specifically, it was observed that the amount of the fatty acid linoleic acid (C18:2) in phospatidylcholine, isolated from human erythrocyte membranes, was decreased in Friedrich's ataxia patients (Huange et al, 1980, this symposium) and that the physical state of human erythrocytes membranes proteins was altered in Friedrich's ataxia patients (Butterfield) et al, 1979). The direction of the alteration is qualitatively consistent with the decrease in linoleic acid (C18:2).

We have sought to obtain additional evidence for a generalized membrane defect in Friedreich's ataxia. To that end we have examined the proteins of human erythrocyte membranes by SDS-polyacrylamide gel electrophoresis before and after a reduction with $\beta$-mercaptoethanol since previous studies have suggested an alteration of its composition (Shapcott et al, 1979, unpublished results; see Draper et al, 1979). The protein kinase activity of human erythrocyte membranes was also determined since in a number of hereditary diseases, in which a defect of the membranes was known, an increase or decrease of its activity was observed (Roses and Appel, 1973 and 1975; Roses et al, 1975; Hosey and Tao, 1976; Dzandu and Johnson, 1980).

\section{MATERIALS AND METHODS} Materials

Eleven Friedreich's ataxia patients (six females and five males) and six controls (three females and three males), which had fasted overnight, were used for our studies. Patients and controls used in a given experiment were age and sex-matched. Blood was drawn by venipuncture in heparin. Reagents for polyacrylamide gel electrophoresis were obtained from Bio-Rad Laboratories; $\left(\gamma-{ }^{32}\right.$ P)-ATP of specific activity 5-9 mci per mole was obtained from New England Nuclear. Solutions of $\left(\gamma^{32} \mathrm{P}\right)$-ATP made were used within a period of two weeks and stored at $-20^{\circ} \mathrm{C}$.

\section{Preparations of erythrocyte membranes}

Erythrocyte membranes were prepared with fresh solutions cooled at $4^{\circ} \mathrm{C}$. Ten milliliters of freshly drawn blood in heparin were centrifuged at $27,000 \mathrm{~g}$ for 20 minutes. After removal of the supernatant and buffy coat the erythrocytes were washed three times with a solution of 310 mosm sodium phosphate buffer, $\mathrm{pH} 7.4$, and lysed with a solution of $5 \mathrm{mM}$ sodium phosphate buffer, pH 8.0. The erythrocyte membranes were collected by centrifugation at $27,000 \mathrm{~g}$ for 15 minutes and washed until white with the lysis buffer. They were then washed twice with a solution of $50 \mathrm{mM}$ $\mathrm{CH}_{3} \mathrm{COONa}, 10 \mathrm{mM} \mathrm{MgCl}_{2}$ and 0.6 $\mathrm{mM}$ EGTA buffer, $\mathrm{pH} 6.5$ and suspended in this washing buffer at a protein concentration of $2-3 \mathrm{mg}$ per milliliter.

\section{Protein kinase assay}

The protein kinase assay was done at room temperature under conditions similar to those of Roses and Appel (1975), using the following procedure: Aliquots of erythrocyte suspension containing $160 \mu \mathrm{g}$ of protein were diluted to a volume of $150 \mu \mathrm{l}$ with a

\section{Abbreviations:}

SDS: sodium dodecyl sulfate; EDTA: ethylene dinitrilo tetraacetic acid: EGTA: ethyleneglycol-bis ( $\beta$-aminoethyl ether); N, N'-tetracetic acid. 
solution of $50 \mathrm{mM} \mathrm{CH} \mathrm{COONa}_{3} 10$ $\mathrm{mM} \mathrm{MgCl}$, and $0.6 \mathrm{mM}$ EGTA buffer, $\mathrm{pH}$ 6.5. The reaction of phosphorylation was then initiated with the addition of $50 \mu \mathrm{l}$ of a solution of $\left(\gamma^{32} \mathrm{P}\right)$-ATP $(30 \mathrm{nmoles} / \mathrm{ml}$ of assay buffer). After 30 seconds the reaction was stopped with the addition of $300 \mu$ l of a solution of $20 \%$ sucrose, $3 \%$ SDS, $1 \% \beta$-mercaptoethanol, $0.005 \%$ bromophenol blue, $1 \mathrm{mM}$ EDTA and $10 \mathrm{mM}$ sodium phosphate buffer, $\mathrm{pH}$ 7.2. Aliquots of $220 \mu \mathrm{l}$ were then submitted to a SDS-polyacrylamide gel electrophoresis according to the procedure of Weber and Osborn (1969). Gels were stained with Coomassie blue and destained. The radioactivity count of the proteins bands was then determined according to a procedure previously described (Wong and Roses, 1979).

\section{Protein determination}

Protein concentration was determined according to Lowry's assay (1951) using a solution of $\mathrm{Na}_{2} \mathrm{CO}_{3}$ made $3 \%$ in SDS. Aliquots of erythrocyte membranes suspension were solubilized with a $1 \%$ SDS solution before protein determination. Bovine serum albumin was used as the standard.

\section{RESULTS}

The proteins of human erythrocyte membranes of controls and Friedreich's ataxia patients were examined by SDS-polyacrylamide gel electrophoresis, after a reduction with $\beta$-mercaptoethanol. The results are shown in Figure 1 and indicate no difference in their composition.

The proteins of human erythrocyte membranes of controls and Friedreich's ataxia patients were also examined by SDS-polyacrylamide gel electrophoresis without reduction with $\beta$-mercaptoethanol, in order to investigate the possibility that the proteins in Friedreich's ataxia patients may be cross-linked via disulfide bonds. The results showed that none of the proteins in Friedreich's ataxia patients were cross-linked via disulfide bonds: the proteins bands which were observed in controls and Friedreich's ataxia patients were the same as those observed when the electrophoresis was done with the human erythrocyte membrane proteins reduced with $\beta$-mercaptoethanol (see Figure 1).

The protein kinase activity of human erythrocyte membranes of controls and Friedreich's ataxia patients was determined. The procedure used involved basically a brief incubation of the erythrocyte membranes with $(\gamma-$ $\left.{ }^{32} \mathrm{P}\right)$-ATP, separation of the proteins by SDS-polyacrylamide gel electrophoresis and determination of the amount of ${ }^{32} \mathrm{P}$ incorporated into the different proteins bands visualized with Coomassie blue.

The results are summarized in Table 1 and show that the protein kinase activity of human erythrocytes of controls and Friedreich's ataxia patients are identical within experimental error.

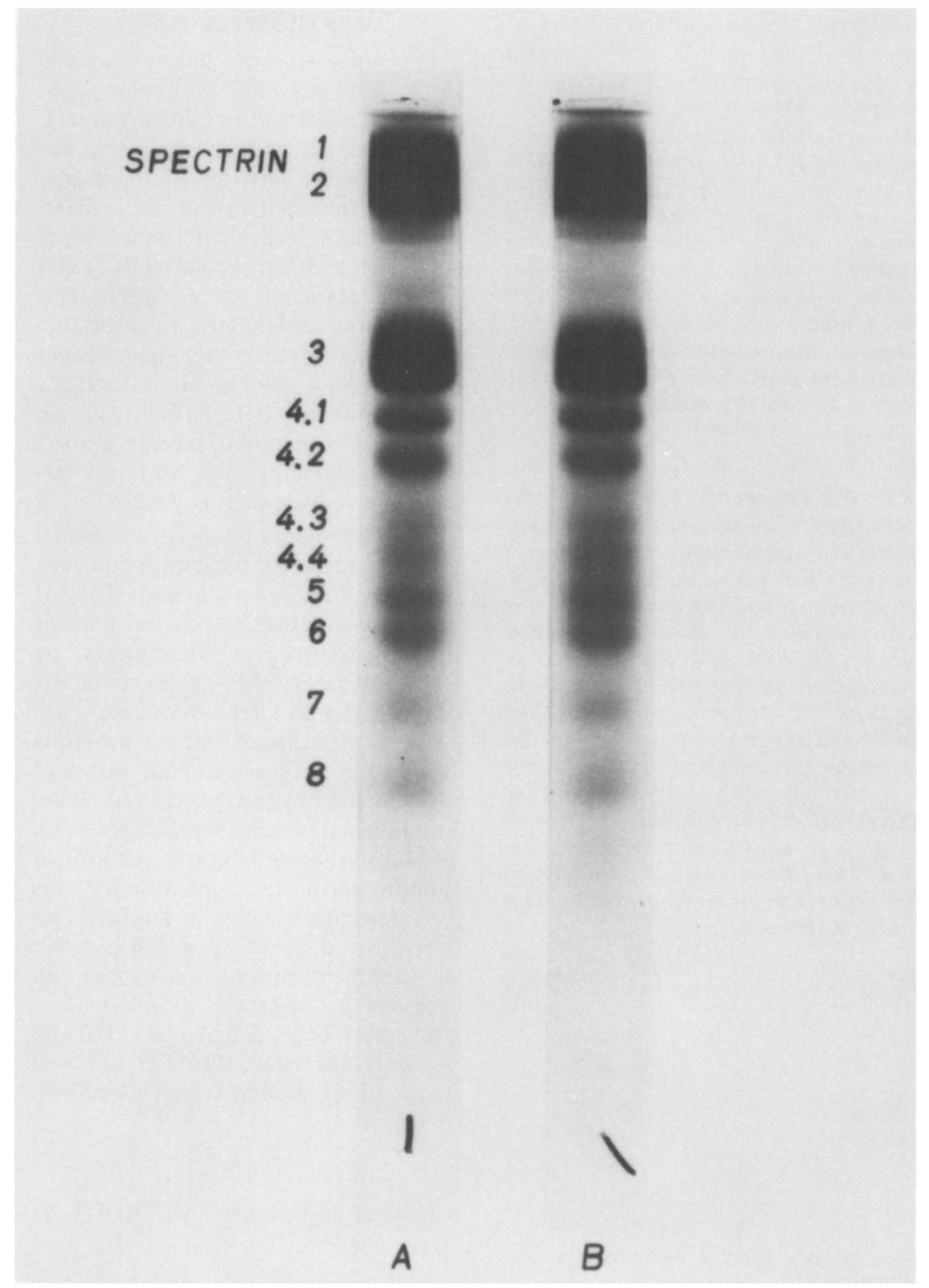

Figure I - Proteins of human erythrocyte membranes of control (Gel A) and Friedrich's ataxia patient (Gel B). Proteins were reduced with $\beta$-mercaptoethanol before electrophoresis. Proteins bands have been numbered according to $a$ nomenclature of Fairbanks et al (1971). 


\section{DISCUSSION}

We have examined the proteins of human erythrocyte membranes by SDS-polyacrylamide gel electrophoresis before and after reduction with $\beta$-mercaptoethanol and have determined the protein kinase activity of human erythrocyte membranes in Friedreich's ataxia patients in order to obtain some additional evidence for a generalized membrane defect in Friedreich's ataxia patients. The results obtained show that the protein composition, the state of aggregation of the proteins and the protein kinase activity are normal in Friedreich's ataxia patients (Figure 1 and Table 1).

There are three conclusions which could be drawn from the above results and results previously reported: (1) There is no generalized membrane defect in Friedreich's ataxia. One has to contemplate this possibility since the alterations of human erythrocyte membranes reported (Draper et al, 1979 and Butterfield et al, 1979) are relatively minor. Other studies done with human erythrocytes have not indicated the presence of major membrane abnormalities (Bureau et al, 1978; Butterfield et al, 1979; Steinberg et al, 1979). (2) There is a generalized membrane defect in Friedreich's ataxia, but this is expressed only minimally in human erythrocyte membranes. The plasma membranes of different tissues are functionally and structurally different. Therefore one should not expect to have the same expression of a generalized membrane defect in all plasma membranes. (3) There is a generalized membrane defect in Friedreich's ataxia but it cannot be detected in human erythrocyte membranes because of the conditions used to prepare them. Conditions of preparation of human erythrocyte membranes have been shown to greatly affect their biochemical properties (Hanahan et al, 1973). Significantly, the alteration of the protein kinase activity in myotonic muscular dystrophy could only be observed under certain conditions of preparations of erythro-

TABLE 1

Amount of $32 P$ Incorporated Into The Proteins Bands Of Human Erythrocyte Membranes Of Controls And Friedreich's Ataxia Patients.

${ }^{32} \mathrm{P}$ incorporated (pmoles $/ \mathrm{ml}$ protein $/ 30 \mathrm{sec}$.)

\begin{tabular}{lll}
\hline Protein Band $^{\mathrm{a}}$ & \multicolumn{1}{c}{ Control } & \multicolumn{1}{c}{$\begin{array}{c}\text { Friedreich's } \\
\text { Ataxia }\end{array}$} \\
\hline $1+2$ (spectrin) & $7.23 \pm 1.99(6)^{\mathrm{b}}$ & $7.33 \pm 2.71(11)$ \\
3 & $1.76 \pm 0.64(6)$ & $1.76 \pm 0.79(11)$ \\
$4.1+4.2$ & $0.51 \pm 0.15(5)$ & $0.59 \pm 0.23(10)$ \\
$5+6$ & $0.36 \pm 0.09(5)$ & $0.43 \pm 0.18(10)$ \\
7 & $0.12 \pm 0.05(4)$ & $0.17 \pm 0.12(7)$ \\
8 & $0.12 \pm 0.05(5)$ & $0.13 \pm 0.11(10)$ \\
\hline
\end{tabular}

a) See figure $I$ for the different proteins bands.

b) The number in parenthesis refers to the number of determinations. Each determination represents the average of two assays.

cyte membranes (Roses and Appel, 1973; Roses and Appel, 1975).

The possibility of a generalized protein membrane defect in Friedreich's ataxia cannot be ruled out, although the present evidence leans to the contrary. Experiments are presently being carried out to investigate these aspects.

\section{REFERENCES}

BUREAU, M.A., BERTHIAUME, Y., BEGIN, R., SHAPCOTT, D., LEMIEUX, B. and CÓTE, M. (1978). Oxygen transport in patients with Friedreich's Ataxia. Can. J. Neur. Sci., 5: 97-99.

BUTTERFIELD, D.A., LEUNG, P.K., MARKENBERG, W.R. and BARBEAU, A. (1979). Evidence for an altered physical state of membrane proteins in erythrocytes in Friedreich's Ataxia. Can. J. Neurol. Sci., 6: 295-298.

DRAPER, P., HUANG, Y.S., SHAPCOTT, D., LEMIEUX, B., BREMAN, M., BARBEAU, A. and DAVIGNON, J. (1979). Erythrocyte membrane lipids in Friedreich's Ataxia. Can. J. Neurol. Sci., 6: 291-294.

DZANDU, J.K. and JOHNSON, R.M. (1980). Membrane protein phosphorylation in intact normal and sickle cells erythrocytes. J. Biol. Chem., 255: 6382-6382.

FAIRBANKS, G., STECK, T.L., WALLACH and D.F.H. (1971). Electrophoretic analysis of the major polypeptides of the human erythrocyte membrane. Biochemistry, 10 , 2606-2617.

HANAHAN, D.J., EKHOLM, J. and HILDENBRANDT, G. (1973). Biochemical variability of human erythrocyte membranes preparations, as demonstrated by sodiumpotassium-magnesium and calcium adenosine triphosphatase activities. Biochemistry, 12: 1374-1387.

HOSEY, M.M. and TAO, M. (1976). Altered erythrocyte membrane phosphorylation in sickle cell disease. Nature, 263: 424-425.

LOWRY, O.H., ROSENBOUGH, N.J., FARR, A.L. and RANDALL, R.J. (1951). Protein measurements with the Folin phenol reagent. J. Biol. Chem., 193: 265-275.

ROSES, A.D. and APPEL, S.H. (1973). Protein kinase activity in erythrocyte ghosts of patients with myotonic muscular dystrophy. Proc. Nat. Acad. Sci. U.S.A., 70: 1855-1859.

ROSES, A.D., HERBSTREITH, M.A. and APPEL, S.H. (1975). Membrane protein kinase alteration in Duchenne muscular dystrophy. Nature, 254: 350-351.

ROSES, A.D. and APPEL, S.H. (1975). Phosphorylation of component a of the human erythrocyte membrane in myotonic muscular dystrophy. J. Membrane Biol., 20: 51-58.

WEBER, K. and OSBORN, M. (1969). The reliability of molecular weight determinations by dodecyl sulfate polyacrylamide gel electrophoresis. J. Biol. Chem., 224: 44064412.

WONG, P. and ROSES, A.D. (1979). Isolation of an abnormally phosphorylated erythrocyte membrane Band 3 glycoprotein from patients with myotonic muscular dystrophy. J. Membrane Biol., 45: 147-166. 